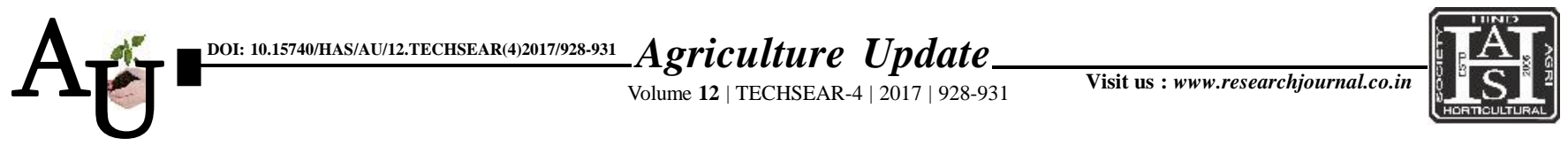

\title{
Research Article: Effect of date of sowing of little millet on shoot fly, Atherigona pulla (Wiedemann) incidence
}

\author{
RAVULAPENTA SATHISH, M. MANJUNATHA, B.K. SHIVANNA, K. \\ RAJASHEKARAPPA, G. K. GIRIJESH AND S. GANGAPRASAD
}

Article Chronicle : Received :

11.07.2017;

Accepted :

26.07.2017

KEY WordS:

SUMMARY : The investigation was carried out on effect of date of sowing of little millet on shoot fly incidence during 2015-16 at Zonal Agricultural and Horticultural Sciences (ZAHRS), UAHS, Hiriyur. The shoot fly incidence was found to be higher in $15^{\text {th }} \mathrm{July}$ to $15^{\text {th }}$ October sown crops. The peak incidence was observed on $15^{\text {th }}$ August (26.26\% deadhearts) and $15^{\text {th }}$ October (24.22\% deadhearts) sown crops whereas low incidence was on $1^{\text {st }}$ May ( $0.70 \%$ deadhearts) sown crop. The higher number of eggs per plant was noticed on $15^{\text {th }}$ August (2.09 eggs/plant) sown crop whereas low on $1^{\text {st }}$ and $15^{\text {th }}$ May (0.29 eggs/plant) sown crops. Shoot fly incidence had direct significant and negative association with the relative humidity.

Little millet, Shoot fly, Date of sowing

How to cite this article : Sathish, Ravulapenta, Manjunatha, M., Shivanna, B.K. Rajashekarappa, K., Girijesh, G.K. and Gangaprasad, S. (2017). Effect of date of sowing of little millet on shoot fly, Atherigona pulla (Wiedemann) incidence. Agric. Update, 12(TECHSEAR-4): 928-931; DOI: 10.15740/HAS/AU/12. TECHSEAR(4)2017/928931.

Author for correspondence :

\section{RAVULAPENTA}

SATHISH

Department of

Agricultural

Entomology, University

of Agricultural and

Horticultural Sciences, SHIVAMOGGA

(KARNATAKA) INDIA

Email: sathishento12

@ gmail.com

See end of the article for

authors' affiliations 